\title{
Napoleon i zadżumieni w Jaffie - piękny obraz..., prawda niestety mniej piękna
}

Słowa kluczowe: René Desgenettes, Claude Royer, Napoleon Bonaparte, Jaffa, epidemia dżumy, zatrucia

Jaffa, portowe miasto położone na wschodnim wybrzeżu Morza Śródziemnego stanowiące dziś przedmieście Tel Awiwu, stała się miejscem wydarzenia utrwalonego na olbrzymim $(5,32 \mathrm{~m}$ wysokości i 7,20 m długości ${ }^{1}$ ) obrazie Antoine'a-Jeana Grosa, wystawionym 18 września 1804 r. podczas Salonu Paryskiego, a przedstawiającym moment odwiedzin Napoleona Bonapartego w lazarecie dla zadżumionych. Do dzisiaj zdobi on jedną z sal paryskiego Luwru i przyciąga wzrok swoją kompozycją zbliżoną do wcześniejszego, powstałego w 1784 r. obrazu Jeana-Louisa Davida „Przysięga Horacjuszy" ${ }^{2}$ Tu również występują arkady dzielące kompozycję na trzy części, w centralnej zaś, z wyraźnym zaakcentowaniem postaci przez smuge blasku, artysta umieścił Napoleona Bonapartego. W układzie tym można odnaleźć bliskie nawiązania do tekstów Pisma Świętego przedstawiających postać Chrystusa uzdrawiającego chorych przez położenie na nich swojej ręki. Dużym walorem jest

${ }^{1}$ Une biographie de Des Genettes, „Le Progres Medical Suppl. Ilustre” 1926, nr 12, s. 91.

${ }^{2}$ E. Castellani, Wielkie muzea. Luwr, Warszawa 2007 (wyd. albumowe br. paginacji). 
dramatyzm samej sceny oraz żywe, choć przy tym mocno skontrastowane barwy, a także ciekawa gra świateł i cieni. Sam temat, jaki prezentuje, popularyzowały również ryciny przygotowywane także $\mathrm{w}$ celach propagandowych jeszcze przed powstaniem samego obra$\mathrm{zu}^{3}$. Zasadniczym celem wizyty głównodowodzącego ekspedycją do Syrii, która odbyła się $9^{4}$ bądź 11 marca 1799 r. ${ }^{5}$, i w której towarzyszył mu naczelny lekarz ekspedycji René Desgenettes, miała na celu w niezwykle spektakularny sposób wpłynąć przede wszystkim na upadające morale armii. Nadwątliły je przypadki coraz liczniej występujących zgonów z powodu szerzącej się gwałtownej choroby. Dość powszechnie brzmiały głosy, że jest to dżuma. Napoleon Bonaparte nie tylko wszedł do budynku, ale także pochylił się nad jednym z chorych i dotknął jego obrzmiałego, zropiałego węzła chłonnego ${ }^{6}$. Był to gest rzeczywiście odważny, ale wypada zadać pytanie, czy na pewno o prawdziwą dżumę tu chodziło. Przypuszczalnie epidemię, która wybuchła w Jaffie, wywołała olbrzymia liczba zwłok, zarówno Francuzów, których w czasie zdobywania miasta zginęło blisko 300, jak i nieustalonej, ale wielokrotnie większej liczby obrońców, których nie zdążono pochować bądź grzebano bardzo płytko, a warto tu nadmienić, że miasta broniły nie tylko regularne oddziały wojska tureckiego ${ }^{7}$. Pod piaskiem wydm nieopodal miasta spoczywały dodatkowo zwłoki blisko 2500 jeńców tureckich wymordowanych na rozkaz Napoleona ${ }^{8}$. Nałożyła się na to jeszcze gwałtowna zmiana klimatu, po długim marszu przez pustynię, gdzie nawet wiosną panowały dość wysokie temperatury, armia znalazła się w znacznie chłodniejszym i wilgotniejszym klimacie wschodniego wybrzeża basenu Morza Śródziemnego. Taką właśnie przyczynę nagłej choroby, która zaatakowała wojska francuskie, podawał m.in. naczelny chirurg Dominique Jean Larrey, spisując poczynione przez siebie obserwacje. A oto krótka notatka skreślona jego ręką, dotycząca zaobserwowanych objawów: „była to postać silnej gorączki, kiedy występowało bądź też nie zapalenie węzłów chłonnych i głębokie czyraki. Choroba ta generalnie nie miała przebiegu śmiertelnego,

\footnotetext{
${ }^{3}$ A. Gerard, Bonaparte et le service de santé au cours de l'expédition d'Egypte, „Histoire des Sciences Medicales” 1974, vol. 8, t. I, s. 117.

${ }^{4}$ A. Schuermans, Itinéraire général de Napoléon Ier, Paris 1911, s. 90.

5 P. Triaire, La visite de Bonaparte aux pestifères, la légende et la vérité, „La Chronique Medicale”, 15 Juin 1902, R. IX, nr 12, s. 374. 324.

${ }^{6}$ G. Barral, La sante de Napoleon Ier, „Chronique Medicale” 1900, R. VII, s. 323-

R. Kark, Jaffa: A City in Evolution 1799-1917, Jerusalem 1990, s. 8-10.

${ }^{8}$ T. Rogacki, Ekspedycja egipska, Zabrze 2008, s. 260-261
} 
lecz wyczerpywała organizm, a poza tym była bardzo bolesna, gdyż

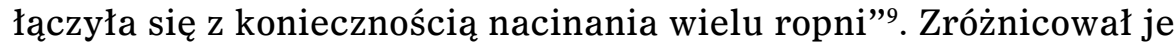
następnie $\mathrm{z}$ całym szeregiem zmian w węzłach chłonnych charakterystycznych dla dżumy dymieniczej ${ }^{10}$, generalnie opisując jako schorzenie „w typie gorączkowym, posiadające wiele analogii do prawdziwej dżumy, przy tym endemiczne dla tego miejsca i panującego tam klimatu" ${ }^{11}$. Jest rzeczą ciekawą, że w swoich zapiskach posługiwał się wielokrotnie określeniem „virus”"12, używając go w zupełnie współcześnie brzmiącej konotacji jako „czynnik, który wywołuje chorobę, i ponadto może przenosić się z jednego na innego osobnika"13.

Dużo bardziej ryzykownemu eksperymentowi niż Napoleon Bonaparte, przeprowadzonemu również $\mathrm{w}$ celu poprawy nastrojów wśród żołnerzy, poddał się naczelny lekarz wyprawy René Desgenettes. O zdarzeniu tym pozostawił $\mathrm{w}$ swoich notatkach następująca wzmiankę: ,żeby uspokoić wyobraźnię, pośrodku szpitala umoczyłem lancet w ropie węzła chłonnego pewnego chorego, zrobiłem sobie lekkie nakłucie $\mathrm{w}$ pachwinie i w okolicach pachy nie stosując żadnych środków ostrożności poza wodą z mydłem"14. Fakt ów wspominają również $w$ swoich tekstach Antoine Thibeadeau ${ }^{15}$, który zaznacza jeszcze, iż: „przez trzy tygodnie tym obu małym ukłuciom towarzyszył ból i stan zapalny, lecz w czasie odwrotu, na oczach wielu żołnierzy Desgenettes kąpał się w morzu w zatoce nieopodal Cezarei" ${ }^{16}$ oraz Etienne Pariset ${ }^{17}$. Warto tu nadmienić, że naczelny lekarz w tak nietypowy sposób nie tylko zaszczepił się, ale także $\mathrm{w}$ tym samym czasie, o czym zresztą też zostawił ślad w swoich wspomnieniach, napił się $\mathrm{z}$ jednego naczynia $\mathrm{z}$ chorym żołnierzem z 75 demi-brigade ${ }^{18}$, aby tym gestem ,jemu i sobie dodać odwagi” ${ }^{19}$.

${ }_{9}$ D.J. Larrey, Relation historique et chirurgicale de l'armee d'Orient en Egypte et en Syrie par D-J. Larrey, Ed. Demonville et soeurs, Paris 1803, s. 124.

10 Tamże.

11 Tamże, s. 130.

12 Tamże, s. 127.

13 Tamże.

${ }^{14}$ R. Sole, Uczeni Bonapartego, Warszawa 2001, s. 89.

15 A. Thibeadeau, Histoire générale de Napoléon Bonaparte, de sa vie privée et publique, de sa carrière politique et militaire, de son administration et de son gouvernements, T. II, Ed. Ponthieu, Paris 1828, s. 237.

16 Tamże.

${ }_{17}^{17}$ Pariset, Eloge du Baron R. Desgenettes, Ed. Balliere, Paris 1838, s. 41.

${ }^{18}$ Nazwa jednostki wojskowej w armii francuskiej funkcjonująca od 1793 do $1803 \mathrm{r}$. Tu za: R. Bielecki, Encyklopedia wojen napoleońskich, Warszawa 2002, s. 474.

${ }_{19}$ A. Gerard, dz. cyt., s. 118. 
Antoine Thibeadeau nadmienia jeszcze, że świadkiem gestu naczelnego lekarza był „obywatel Durand, płatnik pułku kawalerii, który stał w namiocie gdzie leżeli chorzy"20.

Wiarygodność gestu Renégo Desgenettes'a była od samego początku kwestionowana przez Dominika Jeana Larreya ${ }^{21}$, który uważał, że nie doszło tu do kontaktu z prawdziwą dżumą, a jedynie ropnymi zmianami towarzyszącymi panoszącej się w Jaffie i okolicach infekcji, którą - o czym już było wspomniane - starannie opisał. Należy zgodzić się z opinią zaprezentowaną przez tego wybitnego chirurga, tym bardziej iż Patrice Bret w swojej pracy cytuje przykład angielskiego lekarza - niestety nie podając nazwiska ani żadnych innych informacji umożliwiających identyfikację - który trzy lata później chciał powtórzyć tę próbę i w jej wyniku zmarł na dżumę 22 .

Jeszcze ciekawiej przedstawia całą rzecz Hippolyte Larrey - syn Dominika Jeana Larreya, pisząc, iż trudno uznać całe wydarzenie za wiarygodne ${ }^{23}$ chociażby w świetle wypowiedzi samego Desgenettes'a, który w jednej ze swoich notatek zapisał: „i tak to niewinne kłamstewko stało się interesującą historią"24.

$\mathrm{Z}$ prawdziwą dżumą, podówczas stanowiącą jedną $\mathrm{z}$ prawdziwych plag Bliskiego Wschodu, zetknięto się na terenie Egiptu oraz Syrii wielokrotnie i - jak wynika z zestawienia sporządzonego przez wzmiankowanego już Desgenettes'a w zakończeniu sporządzonego przez niego opracowania najważniejszych dokumentów dotyczących ekspedycji do Egiptu ${ }^{25}$ - ogółem z powodu chorób epidemicznych zmarło w czasie kampanii egipskiej 4200 żołnierzy, w tym ok. 2500 właśnie na dżumę ${ }^{26}$. Tomasz Rogacki podaje tu - niestety nie cytując źródła, a jedynie rozpoczynając od nagłówka „Desgenettes” - trochę inne dane, a mianowicie, że $\mathrm{z}$ powodu chorób zmarło 2468, na dżumę zaś 1689 żołnierzy ${ }^{27}$. Na różne sposoby próbowano walczyć z nawracającymi dość regularnie epidemiami. Naczelny chirurg Dominique Jean Larrey szczególnie zwracał uwage na drogi przenoszenia tej

\footnotetext{
${ }^{20}$ A. Thibeadeau, dz. cyt., s. 237-238.

${ }^{21} \mathrm{P}$. Triaire, Dominique Larrey et les campagnes de la révolution et de l'Empire, 1768-1842, Ed. Mame, Tours 1902, s. 249.

${ }_{22}$ P. Bret, Egipt w czasach Napoleona, Poznań 2002, s. 249.

${ }^{23}$ P. Triaire, Dominique Larrey..., dz. cyt., s. 250.

${ }^{24}$ Tamże.

${ }^{25} \mathrm{R}$. Desgenettes, Histoire médicale de l'armée d'Orient par le médecin en chef R. Desgenettes, Paris 1802.

${ }^{26}$ G. Richet, Aspects humanitaires et médicaux de l'Armee d'Orient (1799-1801), „Histoire des Sciences Medicales” 2003, T. 37, nr 2, s. 195.

${ }^{27}$ T. Rogacki, dz. cyt., s. 451.
} 
choroby, i w jednej z jego notatek znaleźć można następujący wers: „na dżumę najlepszym sposobem jest porządek i czystość w oddziałach" ${ }^{28}$. Wraz z Desgenettes'em udało mu się opanować największe zagrożenie epidemiczne, mało tego - śmiertelność, która początkowo wynosiła 8 na 10 chorych, obniżyła się do 3-4 na $10^{29}$. W miastach egipskich, gdzie także wprowadzono kontrolę stanu higienicznego, a następnie w miarę ścisły reżim sanitarny, odnotowano zaledwie 3\% śmiertelności, choć wcześniej utrzymywała się ona na znacznie wyższym poziomie, sięgając $20-25 \%{ }^{30}$.

Dobrym przykładem działań praktycznych podejmowanych podczas kampanii syryjskiej może być m.in. rozporządzenie, które wydał Larrey właśnie w okolicach Jaffy 3 marca 1799 r., a dotyczące utrzymania czystości, obejmujące też zalecenia odnośnie do spożywania posiłków i dostępu do wody pitnej ${ }^{31}$. Wielokrotnie ponawiał również dyspozycje dotyczące spalenia całego dobytku zmarłych żołnierzy, w tym szczególnie ich mundurów. Poszczególne oddziały miały kwaterować poza obrębem murów miejskich, by dochodziło do jak najrzadszego kontaktu $\mathrm{z}$ tubylcami. Larrey poszukiwał również, o czym pisał $\mathrm{w}$ specjalnym raporcie sporządzonym dla Instytutu Egipskiego ${ }^{32}$, samej przyczyny choroby, przeprowadzając w tym celu m.in. sekcje zwłok. Pierwszą przeprowadził w Jaffie na ciele młodego, 25-letniego żołnierza ${ }^{33}$. Działania, które podejmował, również wymagały dużego samozaparcia i odwagi, szczególnie po śmierci jednego z asystentów o nazwisku Betheil, który - jak sam pokrótce zanotował - „zmarł na dżumę w tym mieście [w domyśle w Jaffie], a wiele pomagał mi przy badaniu zwłok i otwieraniu ciał" 34 .

Po raz drugi do Jaffy kolumny armii francuskiej wkroczyły w trakcie wycofywania się po zakończonym niepowodzeniem oblężeniu Saint Jean d'Akre (Akki). Miało to miejsce 24 maja 1799 r. Widząc wyczerpanie żołnierzy, Napoleon zarządził czterodniowy odpoczynek oraz wydał rozkazy odnośnie do dalszej ewakuacji. Na redzie portu stało kilkanaście statków. Były to jednostki różnej wielkości, w tym czte-

\footnotetext{
${ }^{28}$ D.J. Larrey w: Relation historique et chirurgicale..., dz. cyt., s. 141.

${ }_{29}$ M. Cazalas Discours, [w:] Inauguration de la statue du baron Larrey, chirurgien en chef des armées du premier Empire, Ed. T. Thelmon, Tarbes 1864, s. 31.

${ }^{30}$ P. Bret, dz. cyt., s. 143.

${ }^{31}$ H. Wasserman, Jean Dominique Larrey, chirurg Wielkiej Armii, „Medycyna” 1935, R. IX, nr 21, s. 712.

${ }^{32}$ R. Sole, dz. cyt., s. 89.

${ }^{33}$ D.J. Larrey w: Relation historique et chirurgicale..., dz. cyt., s. 130-131.

${ }^{34}$ Tamże.
} 
ry duże okręty: „Le Chebec”, „La Fortune”, „La Chaloupe” i „L’Helene" 35 , nad którymi pieczę sprawował wiceadmirał Honore Joseph Gantheaume, oraz kilka mniejszych jednostek określanych mianem „djerma" ${ }^{36}$. Na ich pokłady, o czym wspomina m.in. Vigo-Roussillon ${ }^{37}$, przeniesiono blisko 1200 osób, głównie rannych, aby ich przewieźć do Damietty w Egipcie. Dla większości okrętów przydzielono personel medyczny, a nadzorującymi lekarzami zostali: dr. dr. Rosel, Andre, Lagin, Javanat, Leclerc, Gleze i Moranges ${ }^{38}$. W notce sporządzonej przez Paula Triaire'a na podstawie dokumentu zachowanego $\mathrm{w}$ bibliotece Larreya znaleźć można trochę inne nazwiska, a mianowicie: Givaud, Ravanate, Laugier, Andre, Glaise, Moranges i Leclerc, który został przydzielony na „L'Helene”39.

Po pierwszej fazie ewakuacji, połączonej z zaokrętowaniem, w mieście pozostało nadal ponad 800 rannych i chorych, wśród których przeważali chorzy na dżumę. Większość rannych udało się Larreyowi przygotować do transportu pod opieką oddziałów straży przedniej, a konkretnie drugiego batalionu 69. demi-brigade. Jednak według Desgenettes'a ${ }^{40}$, pomimo podejmowanych działan, w budynkach zajmowanych przez szpital nadal znajdowali się chorzy. Ich liczbę szacował na ok. 30-40 (d'Aure, który w Armii Orientu pełnił obowiązki ordonnatora ${ }^{41}$, podaje, że było ich $34^{42}$ ), choć w rzeczywistości znajdowało się ich tam o wiele więcej.

27 maja $1799 \mathrm{r}^{43}$ wódz naczelny postanowił sam ocenić sytuację i - jak pisze Louis Bourienne - „Bonaparte energicznie kroczył po salach, uderzając szpicrutą o buty [...] powiedział do chorych «musi-

${ }^{35}$ A. Bulos, Bourrienne et ses erreurs volontaires et involontaires, ou Observations sur ses paires „Mémoires” MM. le général Belliard, le général Gourgaud, le comté d'Aure, le comté de Survilliers, le Bon Meneval, le comté Bonacossi, Paris 1830, s. 36.

${ }^{36}$ Tamże. Była to łódź z charakterystycznym dużym ukośnym żaglem, używana w żegludze na Nilu i po wodach przybrzeżnych wschodniej części Basenu Morza Śródziemnego.

${ }^{37}$ Vigo-Roussillon, L'expedition d'Egypte. Fragment des memoires militaire du colonel Vigo-Roussillon, „Revue des Deux Mondes”, R. LX (Troisieme periode), T. C (1 Juillet 1890), s. 607.

${ }^{38}$ A. Bulos, dz. cyt., s. 37.

${ }^{39}$ P. Triaire, Dominique Larrey..., dz. cyt., s. 256.

${ }^{40}$ E. Forge, Desgenettes, „Société historique et archéologique de l'Orne. Bulletin” 1939, T. LVIII, s. 72.

${ }^{41}$ Ordonnator, tyuł ten jako samodzielna funkcja osoby zawiadującej całością administacji wojskowej szczególnie w kwestiach zaopatrzenia występuje w ówczesnej nomenklaturze, lecz nie ma określenia osobowego. Tu za: Gembarzewski, Wojsko polskie. księstwo Warszawskie 1807-1814, Warszawa 1905.

${ }_{42}$ A. Bulos, dz. cyt., s. 37.

${ }^{43}$ A. Schuermans, dz. cyt., s. 95. 
my wrócić do Egiptu, aby ocalić go przed inwazją, którą planują nasi wrogowie. Za kilka godzin będą tu Turcy i ci z was, którzy czują się na siłach, mogą pójść $\mathrm{z}$ nami. Będą niesieni w koszach lub pojadą na koniach». [...] w szpitalu przebywało co najmniej sześćdziesięciu chorych na dżumę, ale zupełna cisza, w jakiej leżeli, kompletne wyczerpanie i ogólna apatia świadczyły, że ich koniec jest bliski. Zabranie ich $\mathrm{w}$ tym stanie byłoby równoznaczne $\mathrm{z}$ narażeniem reszty armii na zakażenie" ${ }^{44}$.

Po zakończeniu wizytacji Napoleon zaproponował, by podać wszystkim śmiertelną dawkę opium, lecz towarzyszący mu naczelny lekarz stanowczo odmówił. Stało się to już po raz drugi, gdyż pierwszy raz taka propozycja padła pod jego adresem przed wycofaniem się spod Saint Jean d'Akre (Akki), o czym tak wspomina sam René Desgenettes: „Bonaparte wezwał mnie do namiotu, gdzie siedział tylko z szefem sztabu [generałem Aleksandrem Berthierem]. Po krótkiej rozmowie na temat ogólnej sytuacji medycznej rzekł do mnie: «gdybym był na pańskim miejscu, skróciłbym męki wszystkim chorym na dżumę i uchronił ich przed czekającym niebezpieczeństwem, podając im opium». Odparłem krótko: «moim obowiązkiem jest ratować ludzkie życie» [w tym miejscu należy zadać pytanie, czy w Jaffie nie doszło po raz drugi do takiej rozmowy, wskazuje na to wers z pamiętnika Vigo-Roussilona ${ }^{45}$, gdzie powyższe słowa są zapisane w sposób brzmiący jednakowo]. W rezultacie generał zaczął mi po cichu wyjaśniać, że nie oczekuje od innych robienia czegoś, czego nie zrobiłby sam [...] generał Berthier przez całe spotkanie zachowywał milczenie [...] potem jednak dał mi do zrozumienia, że popiera moją odmowę" ${ }^{46}$. Drugi ze świadków zdarzenia w swoich wspomnieniach nic nie pisze na ten temat, nadmieniając jedynie, że „pod osłoną nocy ewakuowano chorych i rannych pierwszego konwoju, który wyruszył 26 Floreala [15 maja], strzegł pierwszy batalion 69 demi-brigade, a drugiego, który wyruszył 30 Floreala [19 maja] drugi batalion" ${ }^{47}$. Tym razem jednak Napoleon nie miał zamiaru ustąpić i nakazał sprowadzenie tureckiego lekarza ze Stambułu, Hadża Mustafę, członka załogi jednego ze statków, która wprowadziła jednostkę do portu, nie wiedząc o tym, że

${ }^{44}$ L.A. Fauvelet de Bourienne, Memoires, T. II, Ed. A. Wahlen \& H. Tablier, Bruxelles 1829, s. 208-209.

${ }^{45}$ Vigo-Roussillon, dz. cyt., s. 607.

${ }^{46}$ C. de La Jonquiere, L'expedition en Egypte, 1798-1801, T. IV, Paris br. r. wyd., s. 556.

47 A. Berthier, Relation des campagnes du General Bonaparte en Egypte et en Syrie par le général de division Berthier chef de l'etat major general de l'Armee d'Orient, Milan An. VIII, s. 77. 
miasto znajdowało się w rękach Francuzów. Miał on przy sobie dość duży zapas laudanum, przy czym, jak pisze A. Gerard, były to dwa flakony zawierające w sumie ok. sześciu litrów substancji ${ }^{48}$. Ilość trochę niewiarygodna, jeśli chodzi o wymieniony z nazwy specyfik, stąd można wysnuć przypuszczenie, że ów medyk posiadał trudną dziś do ustalenia, jeśli chodzi o dokładny skład, mieszankę zawierającą ekstrakt maku anatolijskiego należącego do gatunku Papaver setigerum. O tej regionalnej odmianie, noszącej miano „maku trojańskiego” ${ }^{49}$, zawierającej inną proporcję alkaloidów opium niż w należącym do tej samej rodziny Papaver somniferum ${ }^{50}$, lecz - co jest charakterystyczne - dość często używanej na Wschodzie nie tylko w celach leczniczych, lecz także często kryminalnych, wspominał już w 1546 r. francuski podróżnik Belon ${ }^{51}$. W podobny sposób o „mieszance narkotycznej” 52 pisze w swojej pracy Emile Forgue. Wraz z naczelnym farmaceuta Royere'em zaczęli podawać ową nalewkę chorym żołnierzom. Według naocznego świadka prawdopodobnie śmiertelną dawkę otrzymało w sumie 25 pacjentów ${ }^{53}$, ale „kilku z nich zwymiotowało, poczuło się lepiej, wyzdrowiało i mogło opowiedzieć całą historię"54.

Ciekawą wzmiankę na temat tego, cóż to mogła być za mikstura, znaleźć można również u Emmanuela de Las Casesa: „otóż w obozie naszym brakowało wszelkiego rodzaju leków, czemu starano się zaradzić poprzez przygotowywanie mikstur na bazie miejscowych roślin, rozmaite ziółka miały ohydny smak" 55 . Nadmienił dalej, że wykazywały one pewne właściwości odurzające.

Fakt użycia specyfiku o tureckiej proweniencji znajduje swoje potwierdzenie w obszernej pracy zbiorowej Victoires, conquêtes, desastres, revers et guerres civiles des Français de 1792-1815, gdzie w rozbudowanym przypisie dotyczącym ponownego pobytu wojsk francuskich w Jaffie znaleźć można m.in. taki wers: „nie było prawdziwego opium, żeby przygotować nalewkę zwaną potocznie laudanum de Sy-

${ }^{48}$ A. Gerard, dz. cyt., s. 122.

${ }^{49}$ S. Pignatti, Flora d'Italia, Vol. I, Edagricole, br. m. wyd. 1982, s. 353.

${ }^{50}$ Różnica dotyczy ilości chromosomów. Papaver setigerum jest tetraploidem, a $\mathrm{Pa}$ paver somniferum - diploidem. Tu za: V. La Valva, S. Sabato, G. Siniscalso-Gigliano, Morphology and Alkaloid Chemistry of Papaver setigerum DC. (Papaveraceae), „Taxon” May 1985, vol. 34, no. 2, s. 191-196.

${ }_{51}$ P. Kubikowski, H. Wardaszko-Łyskowska (red.), Zależności lekowe, Warszawa 1978, s. 16.

${ }^{52}$ E. Forge, dz. cyt., s. 73.

53 J. de Metz, G. Legrain, Aux pays de Napoleon. Egypte, Grenoble 1913, s. 65.

${ }^{54}$ C. de La Jonquiere, dz. cyt., s. 577.

${ }^{55}$ E. de Las Cases, Memoriał ze Św. Heleny, Gdańsk 2008, s. 179. 
denham, więc zwrócono się do tureckiego lekarza, żeby udostępnił odpowiednią porcję swoich leków"56.

Notatkę o całym wydarzeniu sporządził również bardzo prostym szyfrem (zamiast słów pisał tylko pierwsze litery oddzielone kropkami) generał Jean-Baptiste Kleber, i brzmiała ona: „zasugerowano lekarzom, by podali opium chorym mającym gorączkę i poważnie rannym"57.

Również Vigo-Roussillon zanotował o tym fakcie kilka słów: „o ile pamiętam, ogólna opinia, jaka panowała wśród żołnierzy, wskazywała na to, że chorzy zostali otruci, a w Jaffie pozostawiono nie tylko wielu zadżumionych, ale także ciężko rannych po amputacjach, którzy nie rokowali wyleczenia" 58 .

Sam fakt podania chorym trucizny utrwalił również $\mathrm{w}$ swoich wspomnieniach jeden $\mathrm{z}$ oficerów artylerii Ch. Richardot: „przygotowano chorych i rannych do ewakuacji, zaś tym, którzy nie nadawali się do transportu, żeby nie wpadli w ręce Turków, podano dużą dozę opium"59.

Czy po upływie ponad 200 lat jesteśmy w stanie odtworzyć bieg wydarzeń i choć w przybliżeniu poznać liczbę ofiar? Całe zdarzenie jest na ogół opisywane dość marginalnie, co zmusza do korzystania z publikacji pochodzących z XIX w. Jeśli chodzi o okres późniejszy, zgodzić się trzeba z opinią wyrażoną w 2013 r. przez Christiana Humbrechta, który użył tu współczesnego, dosadnego określenia, że sprawę „zamieciono pod dywan"60. Do najważniejszych prac należy pokłosie konferencji „La Campagne d'Egypte. Mythes et réalités: actes du colloque des 16 et 17 juin 1998"61, a także cykl artykułów Alaina Pigearda zamieszczanych na łamach „Gloire et Empire”62 oraz rozproszone prace zamieszczane na łamach „Histoire des sciences medicales”63. W bibliografii podawanej przez Bibliotekę Narodową Francji

56 „Victoires, conquêtes, desastres, revers et guerres civiles des Français de 17921815”, Ed. Panckoucke, T. X, Paris 1818, s. 312.

57 Tu za: J. Thiry, Bonaparte en Egypte, Paris 1978, przypis s. 379.

${ }^{58}$ Vigo-Roussillon, dz. cyt., s. 607-608.

$59 \mathrm{Ch}$. Richardot, Relation de la campagne de Syrie specialement des sieges de Jaffa et de Saint jean d'Acke par un officier d'artilerie de l'Armee d'Orient, Paris 1839, s. 53.

${ }^{60}$ Conférence „1798 Bonaparte en Egypte” 2. XII. 2013. Présentation J.-N. Bret, http://www.emperi-museum.org/association.html [dostęp: 21.08.2017].

${ }^{61}$ „La campagne d'Égypte, 1798-1801 mythes et réalités” Actes du colloque des 16 et 17 juin 1998 à l'Hôtel national des Invalides, Ed Maissonenuve et Larose, Paris 1998.

62 A. Pigeard, Y. Martin, Mont-Thabor - Saint-Jean-d'Acre - Aboukir Dossier du mois, „1798-1801 La Campagne d'Égypte” 2006, nr 7, cz. 2.

${ }^{63} \mathrm{http}$ ://www3.biusante.parisdescartes.fr/revue-hsm/index [dostęp: 21.08.2017]. 
dla lat 2000-2017 ${ }^{64}$ znaleźć można 90 pozycji, lecz w większości są to opracowania krytyczne tekstów pochodzących z XIX w. bądź dzieła o charakterze ogólnym.

Zapowiedzi wydawnicze donoszą, że w planach edytorskich są trzy publikacje, które $\mathrm{z}$ całą pewnością będą stanowiły cenne uzupełnienie tematu. Pierwszą z nich jest praca Jeana-François Hutina La campagne d'Égypte une affaire de santé: 1798-1801, drugą biografia Renégo Desgenettes'a, której autorem jest Henri Ducoulombier, a ostatnią sytnetyczny przegląd wydarzeń autorstwa Jacques'a-Oliviera Boudona pt. La campagne d'Egypte, ale przed zapoznaniem się z ich treścią trudno jednoznacznie wyrokować, jakie treści zawierają ${ }^{65}$.

Nie inaczej jest, jeśli chodzi o dostępność tekstów w języku polskim. Publikacje poświęcone kampanii w Egipcie i Syrii zajmują się raczej sferą działań militarnych i naukowych. Tak m.in. czyni Tomasz Rogacki w swoich dwóch pracach ${ }^{66}$. Prócz maleńkiego, ale bardzo intersującego zbiorku wspomnień Kampania egipska autorstwa Józefa Szumlańskiego ${ }^{67}$ pozostałe prace dotyczące tego okresu to przekłady $z$ języka fracuskiego ${ }^{68}$ oraz angielskiego ${ }^{69}$, przy czym $w$ tej ostaniej - autorstwa Paula Stratherna - znaleźć można najobszerniejszą wzmiankę w języku polskim dotyczącą omawianego zagadnienia ${ }^{70}$.

Od samego początku fakt ów również nie był powodem do dumy ani do utrwalenia go nawet w osobistych wspomnieniach, stąd m.in. naoczny świadek, którym z całą pewnością mógł być Desgenettes, pierwszą wzmiankę: „tuż przed naszym opuszczeniem Jaffy, o czym mogę zaświadczyć, w szpitalu pozostało 25-30 chorych na dżumę, którym kazano podać dużą dawkę laudanum, z których część z nich ją zwróciła" - zamieścił dopiero w drugiej edycji swojej Histoire medicale de l'Armee d'Orient ${ }^{71}$, która ukazała się drukiem w latach 30. XIX w., a następnie ponowił ją w trzeciej ${ }^{72}$. Jest to oznaczony literą $\mathrm{H}$ odnośnik do zasadniczego tekstu znajdującego się na stronach 82

\footnotetext{
${ }^{64}$ https://catalogue.bnf.fr/affiner [dostęp: 21.08.2017].

${ }^{65} \mathrm{https} / / /$ www.napoleon.org/magazine/livres [dostęp: 12.08.2018].

${ }^{66}$ T. Rogacki, Egipt 1798-1801, Warszawa 1999; T. Rogacki, Ekspedycja egipska..., dz. cyt.

67 J. Szumlański, Wpyprawa egipska roku 1798, Lublin 2016.

${ }^{68}$ P. Bret, dz. cyt.; R. Sole, dz. cyt.

${ }^{69}$ P. Strathern, Napoleon w Egipcie. Największa sława, Poznań 2009.

${ }^{70}$ Tamże, s. 416-418.

${ }^{71}$ R. Desgenettes, Histoire medicale de l'Armee d'Orient par R. Desgenettes, Ed. Firmin Didot, Paris 1830, s. 245.

${ }^{72}$ Tu za: A. Gerard, dz. cyt., s. 121.
} 
i 83 (w pierwszym wydaniu jest identyczna paginacja ${ }^{73}$ ), a będącego zapisem dokumentu wydanego w kwaterze głównej „przed Akką 27 Floreal An VII (16 V 1799)"'74, w którym m.in. znajduje się informacja, że szpitale są przepełnione, a Dr. Vallat, ekonom szpitalny oraz pielęgniarze pracujący $\mathrm{w}$ jednym $\mathrm{z}$ nich również padli ofiarą epidemii ${ }^{75}$. René Desgenettes rozpoczął przypis wiele mówiącym zwrotem ,jest już czas najwyższy, żeby przypomnieć o pewnej ważnej sprawie"76, opisując następnie całe zdarzenie, zakończył go zaś następującą frazą: ,,pierwszy konsul nie utrwalił tego w swoich wspomnieniach, a tym bardziej zapomniał o nim jako cesarz"77.

O wydarzeniach, do jakich doszło w Jaffie, nie wspomina Larrey, co może słusznie zwracać uwagę, ale jest rzeczą łatwo zrozumiałą, jeśli uwzględni się rok pierwszego - i zarazem jedynego za życia autora - wydania Memoires de Chirurgie ${ }^{78}$, a tym bardziej poświęconego w całości kampanii egipskiej Relation historique et chirurgicale de l'expedition de l'Armee d'Orient en Egypte et en Syrie ${ }^{79}$. Paul Strathern w swojej pracy ${ }^{80}$ pisze co prawda, że pomimo tego, iż był on z cała pewnością świadkiem zaistniałej sytuacji, zaprzeczał później temu, co się stało, jednak nie podaje odnośników do żadnych dowodów bezpośrednich, co czyni rzecz trudną do zweryfikowania. Podobnie o rozmowie Napoleona Bonapartego z Desgenettesem i Larreyem wspomina też Tomasz Rogacki, lecz i on nie podaje bliższych danych ${ }^{81}$. Warto jednak pamiętać, że - a na to zwraca uwagę Paul Triaire ${ }^{82}$ - obaj lekarze, pomimo dzielących ich pewnych różnic charakterologicznych, gdy rzecz szła o pomoc rannym i chorym, byli do siebie niezwykle podobni, stąd odpowiedź Larreya, gdyby to do niego było zaadresowane pytanie, które skierował Napoleon Bonaparte do Desgenettes'a, zabrzmiałaby równie jednoznacznie, wyrażona przy tym z pewnością w sposób zdecydowanie bardziej bezkompromisowy i dosadny.

${ }^{73}$ R. Desgenettes, Histoire médicale de l'armée d'Orient par le médecin en chef R. Desgenettes, Paris 1802.

${ }^{74}$ Tamże, s. 82-83.

75 Tamże.

76 Tamże, s. 245.

77 Tamże, s. 246.

${ }_{78}$ D.J. Larrey, Memoires de chirurgie militaire et campagnes de D. J. Larrey, t. I, II, III, Ed. J. Smith, Paris 1812 oraz D.J. Larrey, Memoires de chirurgie militaire et campagnes du baron D-J Larrey, t. IV, Ed. J. Smith, Paris 1817.

${ }^{79}$ D.J. Larrey, Relation historique et chirurgicale de l'expedition de l'Armée d'Orient en Egypte et en Syrie, Paris 1803.

${ }^{80}$ P. Strathern, dz. cyt., s. 417.

${ }^{81}$ T. Rogacki, Ekspedycja egipska..., dz. cyt., s. 301.

${ }^{82}$ P. Triaire, Dominique Larrey..., dz. cyt., s. 261. 
Co do bezpośredniego uczestnictwa Larreya w tej wizytacji szpitala można mieć pewne obiekcje jeszcze $\mathrm{z}$ innego powodu. Otóż $\mathrm{w}$ tym samym czasie kończono już przenoszenie rannych i chorych na jednostki pływające, a jednocześnie formowano konwój z rannymi, którzy mieli być ewakuowani drogą lądową, tak więc jako naczelny chirurg mógł być tam zajęty. Wskazuje na to dokument cytowany przez Paula Triaire'a ${ }^{83}$, a skierowany do „chirurga I klasy Rozeta”"84, o wyznaczeniu chirurgów, którzy będą się zajmowali chorymi na poszczególnych okrętach. Fakt obecności przez cały czas Larreya wśród rannych, $\mathrm{w}$ tym również tych, którzy zostali poszkodowani w czasie marszu z Saint Jean d'Akre (Akki) do Jaffy, potwierdza też w swojej pracy Karl Friedrich Marx, zaznaczając, że „,był to jeden z aktów dramatu, w którym Desgenettes i Larrey grali rolę szlachetnych i odważnych ludzi w pojedynku z «pierwszym człowiekiem świata»" łym zajściu mógł dowiedzieć się już po fakcie.

Jest też rzeczą ciekawą, że w adnotacjach na marginesie pierwszego wydania Memoires, a dotyczących kampanii syryjskiej, które prześledził Paul Triaire, znalazł on dopisek, że: „w armii brakowało wszystkiego, a już szczególnie takich leków, jak opium i laudanum" ${ }^{\text {"6 }}$. Ponadto zachowała się notatka, że w końcowej fazie ewakuacji w pomieszczeniach sąsiadujących ze szpitalem wybuchł pożar, co dodatkowo utrudniało podejmowanie energiczniejszych działan - o czym bezpośrednio również wspominał w dopiskach, odnalezionych dla odmiany przez Jeana Marchioniego ${ }^{87}$ - sam Dominique Jean Larrey. Ostatnią grupą, którą udało się wynieść z zagrożonych budynków, zaopiekował się osobiście, „przecinał ich wrzody, oczyszczał oraz opatrywał podczas marszu przez pustynię"88 i praktycznie wszyscy przeżyli, a jak wynika z raportu, który złożył na ręce komisarza wojennego o nazwisku Daure, z liczącej w sumie kilkuset rannych drugiej partii ${ }^{89}$ (w całym, o czym już wspomniano, znajdowało się ich blisko 800) konwoju, jaki poruszał się trudną drogą lądową, zmarło zaledwie 25 najciężej poszkodowanych ${ }^{90}$.

\footnotetext{
${ }^{83}$ Tamże, s. 256.

${ }^{84}$ Tamże.

${ }^{85}$ K.F.H. Marx, Moral aspects of medical life, London 1846, s. 254.

${ }^{86}$ P. Triaire, Dominique Larrey..., dz. cyt., s. 259.

87 Tu za: J. Marchioni, Place a Monsieur Larrey, Arles 2003, s. 236.

${ }^{88}$ Tamże. Notkę tę cytuje również P. Triaire. Tu za: Dominique Larrey..., dz. cyt., s. 258.

${ }^{89} \mathrm{O}$ tym, że konwoje były dwa, w tym każdy liczył ok. 500 rannych i chorych, wspomina także J. Chanut. Tu za: J. Chanut, Campagne de Bonaparte en Egypte et en Syrie par un officier de la 32 demi-brigade, Paris 1832, s. 100.

${ }^{90}$ P. Triaire, Dominique Larrey..., dz. cyt., s. 269.
} 
Po powrocie do Kairu, podczas posiedzenia Instytutu Egipskiego, które odbyło się 4 lipca 1799 r., doszło do ostrego starcia między Reném Desgenettes'em a Napoleonem Bonapartem. Z zachowania tego drugiego widać było bardzo wyraźnie, że próbował zatuszować swoją decyzję z Jaffy. Po krytyce działań medycznych, którą wygłosił, nie przebierając przy tym w słowach, winą za śmierć chorych, spowodowaną niewłaściwym rozpoznaniem panującej epidemii, obarczył naczelnego lekarza. Desgenettes odpowiedział, jak zanotował jeden ze świadków, ,jeszcze bardziej gorzkim i sarkastycznym komentarzem, chciał też, by wszyscy dowiedzieli się, że honorowo odmówił wzięcia udziału w czynie, który uważał za przestępczy, czyniąc tym samym aluzję do planu otrucia ofiar dżumy"91. Nie mógł dokończyć swojego wystąpienia, gdyż w drzwiach wiodących do sali obrad stanęli zaniepokojeni rozgwarem żołnierze. Wówczas z jego ust padło dość enigmatyczne, a skierowane bezpośrednio do Napoleona Bonapartego zdanie: „a jak określiłby pan naukę prowadzących podoboje i to co w ich trakcie dokonują"92.

Rzecz kolejna - ile tak naprawdę było ofiar. Można spotkać tu liczbę nawet 570, którą podaje cytowany przez A. Gerarda autor brytyjski Robert Wilson ${ }^{93}$, ale wydaje się ona mało wiarygodna, podana raczej w celu dyskredytacji Francuzów, na co dla odmiany zwraca uwagę Paul Triaire ${ }^{94}$.

Warto poświęcić chwilę uwagi akapitowi z książki Roberta Wilsona. Otóż pisze on m.in.: „Buonaparte znalazł aptekarza który zgodził się przygotować truciznę dla chorych. W nocy zmieszał ją ze specjalnie przyrządzonym smacznym posiłkiem, po czym podał niczego nieświadomym chorym i już kilka godzin później 570 żołnierzy zmarło nie za swój kraj, ale za swojego idola"95. Już po lekturze tych kilku fraz trudno odmówić racji Paulowi Triairemu, że tekst ten był napisany w określonym celu i był on daleki od przekazu faktów rzeczywistych.

Równie dużą i równie mało wiarygodną liczbę podaje w swoich zapiskach Louis Constant ${ }^{96}$, łącząc ją z kłótnią między marszałkiem Jeanem Lannesem a marszałkiem Jeanem-Baptistem Bessieresem, do której miało dojść 22 maja 1809 r., tuż przed bitwą pod Aspern-Essling, gdy

${ }_{91}$ Tu za: „Victoires, conquêtes, désastres, revers et guerres civiles des Français de 1792-1815”, Paris 1818, T. X, s. 313-314.

${ }_{92}$ P. Bret, dz. cyt., s. 191.

${ }_{93}$ A. Gerard, dz. cyt., s. 122.

${ }^{94}$ P. Triaire, Dominique Larrey..., dz. cyt., s. 257-258.

${ }_{95}$ R.T. Wilson, History of the British expedition to Egypt, London 1803, s. 119.

${ }^{96}$ A. Gerard, dz. cyt., s. 122. 
pierwszy zarzucał drugiemu udział „,w otruciu 300 biednych chorych w Jaffie" ${ }^{97}$. O zdarzeniu tym wspomina również Cadet de Gassicourt, pisząc „dzielny Montebello ${ }^{98}$ nie zapomniał nigdy *** [w tekście zamiast nazwiska podaje trzy asteryski] śmierci trzystu biednych Francuzów w Jaffie, których zostawiono w tym mieście, kiedy opuściła je armia" $"$.

Bezpośredni świadkowie z epoki, choć niekoniecznie uczestniczący w wydarzeniach, podają liczbę ofiar od 87, jak wspomina Jean-Antoine Chaptal ${ }^{100}$, przez 60, o czym dla odmiany piszą wspomniany już Louis Bourienne ${ }^{101}$ oraz Cadet de Gassicourt ${ }^{102}$, ok. 50, gdyż taką liczbę można znaleźć w cytowanym uprzednio dziele Victoires, conquêtes, désastres, revers et guerres civiles des Français de 1792-1815 ${ }^{103}$, do 25-30, a tę ostatnią wartość znaleźć można w najczęściej cytowanych wspomnieniach Desgenettes'a ${ }^{104}$, natomiast Antoine Thibeadeau ocenia ich liczbę w przybliżeniu na od 15 do $18^{105}$. Angielski admirał Sidney Smith, który na czele wojsk brytyjskich wkroczył do miasta zaledwie kilka godzin po opuszczeniu go przez wojska francuskie, zanotował m.in.: „niepogrzebane zwłoki Francuzów leżały na trupach tych, których Francuzi zmasakrowali dwa miesiące wcześniej [...] w szpitalu pozostało siedmiu żywych nieszczęśników, którzy otrzymali od nas opiekę i ochronę"106.

Jak pisze Emmanuel de Las Cases w swojej obszernej pracy Memoriat ze Św. Heleny ${ }^{107}$ : „wielki marszałek Bertrand, który również służył w Armii Egiptu [...] był święcie przekonany, że otruto 60 chorych”108, kontynuując następnie: „w krytycznej chwili to nie naczelny dowódca, lecz któryś z lekarzy zaproponował podanie opium [...]

97 Tamże.

98 Marszałek Jean Lannes nosił tytuł księcia Montebello. Tu za: R. Bielecki, dz. cyt., s. 346.

99 „Voyage en Autriche, en Moravie et en Bavière fait a la suite l'armee française pendant la campagne de 1809 par c. L. Cadet de Gassicourt”, Paris 1818, s. 120.

100 J-A. Chaptal, Mes souvenirs de Napoleon, Paris 1893, s. 375.

101 L.A. Fauvelet de Bourienne, dz. cyt., s. 209.

102 „Voyage en Autriche, en Moravie et en Bavière fait a la suite l'armee française pendant la campagne de 1809 par c. L. Cadet de Gassicourt”..., dz. cyt., s. 391.

103 „Victoires, conquêtes, desastres, revers et guerres civiles des Français de 1792$1815 ” . . .$, dz. cyt., s. 312.

$104 \mathrm{Tu}$ za: A. Gerard, dz. cyt., s. 122.

105 A. Thibeadeau, dz. cyt., s. 272.

106 J. Barrow, Life and Correspondence of Admiral Sir William Sidney Smith, T. 1, London 1848, s. 313.

107 E. de Las Cases, dz. cyt.

108 Tamże, s. 178. 
zaś Anglicy znaleźli jednego lub dwóch żywych"109. Kilka wersów dalej zmienia jednak dopiero zapisane fakty i podaje, że w szpitalu pozostało zaledwie 20 chorych, a „Napoleon zapytał naczelnego lekarza czy nie będzie aktem miłosierdzia podanie im opium"110. Czy to pamięć zawodziła tu cesarza? Istniał wszak notatnik generała Jeana-Baptiste'a Klébera, który bardzo prostym szyfrem - do zapisu używał tylko odwróconych dużych liter - zanotował: ,zaproponował [w domyśle, co sugeruje zniekształcony zaimek osobowy] oficerom służby zdrowia, aby podali opium wszystkim gorączkującym i cięzko rannym"111.

O wydarzeniach, do których doszło w Jaffie, Napoleon wspominał również, chociaż nie bezpośrednio, generałowi Henriemu-Gratien Bertrandowi, który przebywał razem z nim na Wyspie Świętej Heleny. Notował on, również szyfrując, większość wypowiedzi cesarza i pod datą 5 maja 1817 r. zapisał m.in.: „nie mogłem zostawić naszych chorych, by stali się jeńcami tureckimi, żeby ich napojono roztopionym ołowiem, gdyby moja żona czy mój syn nie nadawali się do transportu, uczyniłbym dla nich też taki akt łaski" 112 .

Temat ten stał się także osnową jednej z rozmów przeprowadzonych z Williamem Wardenem, angielskim chirurgiem, do której doszło na pokładzie „Northumberland” podczas rejsu na Wyspę Świętej Heleny ${ }^{113}$. Sprowokowała go do tego przypuszczalnie lektura cytowanego powyżej akapitu z książki Roberta Wilsona ${ }^{114}$, w którym została m.in. podana tak wielka liczba ofiar otrucia chorych w Jaffie. Jak zanotował William Warden, „Napoleon wyraźnie powiedział, iż w szpitalu zostało siedmiu chorych na dżumę. Dodał jeszcze, że usłyszał od naczelnego lekarza, którym był chyba Desgenettes, że w przeciągu 24 godzin będą martwi, zapytałem dlaczego $\mathrm{w}$ takim razie Wilson mówi o większej liczbie, odpowiedział kontynuując myśl, 57 czy 67 to byli wszyscy ranni i chorzy w tym lazarecie"115.

Innym ciekawym, acz gmatwającym nieco obraz przyczynkiem dotyczącym tego samego tematu, jest kolejne wspomnienie Emmanuela

109 Tamże.

110 Tamże, s. 179.

111 Tu za: P. Strathern, dz. cyt., s. 418.

112 F.de Langle, Général Bertrand. Cahiers de Sainte-Helene, Paris 1951, s. 128.

113 Dr. Cabanes, A. Blavihnac, Correspondance de Guillaume Warden chirurgien à bord du vaisseau de Sa Majeste britannique le „Northumberland” qui a conduit Napoléon Bonaparte a l'île de Saite-Helene, „La Chronique Medicale”, 1re Decembre 1899, R. VI, nr 23, s. 737-742.

${ }^{114}$ R. Wilson, Histoire de l'expedition de l'Armee britannique en Egypte, Whitehall 1803.

115 Dr. Cabanes, A. Blavihnac, dz. cyt., s. 739. 
de Las Casesa, jakie znaleźć można w Memoriale ze Św. Heleny, w którym używa on określenia „naczelny lekarz”"116, nie podając bliżej, kogo określa tym mianem. Czyżby to był René Desgenettes, a może chodziło tu o naczelnego farmaceutę. Ten ostatni nie był człowiekiem o nieposzlakowanej uczciwości. Otóż, o czym wspomina Victoires, conquêtes, désastres, revers et guerres civiles des Français de 1792-1815 ${ }^{117}$, miał on sprzeniewierzyć środki przeznaczone na zakup zaopatrzenia w niezbędne leki armii wyruszającej do Syrii, a po udowodnieniu winy, do czego doszło pod murami Saint Jean d'Acre (Akki) ${ }^{118}$, skazany na karę śmierci przez rozstrzelanie, po czym na prośbę lekarzy jednak ułaskawiony. Przypuszczalnie nie było to pierwsze nadużycie, jakiego dopuścił się naczelny farmaceuta, gdyż w skład komisji, której zadaniem było przygotowanie od strony zaopatrzenia medycznego kampanii syryjskiej, weszli René Desgenettes, Dominique Jean Larrey i jako farmaceuta Jean-Pierre Boudet (przejął obowiązki naczelnego farmaceuty 2 września $1800 \mathrm{r}^{119}$ ), nie wspomina się natomiast o faktycznym naczelnym farmaceucie Royerze ${ }^{120}$. Jak dalej pisze Emmanuel de Las Cases, gdy Francuzi opuścili Egipt, pozostał w tym kraju i nadal pełnił swoje obowiązki, a po kolejnych malwersacjach został znów uwolniony od kary, przy czym „utrzymywał, że to właśnie on sam podał zgodnie $\mathrm{z}$ jego [w domyśle Napoleona] rozkazami opium chorym na dżumę"121.

O postaci naczelnego farmaceuty pisze też Cadet de Gassicourt, „gdy zgodnie z prawdą Desgenettes odmówił, On [Napoleon] kazał przybyć naczelnemu farmaceucie panu Royerowi, człowiekowi bardzo słabemu, i kazał chorym dać opium [...] usłuchał bez wahania", dalej zaś, cytując słowa Desgenettes'a, pisał: „generał kazał mi natychmiast wrócić do obozu i rozkazał milczeć” i następnie dodaje: „zrobiłem ostre wyrzuty Monsieur Royer, skrytykowałem go, mówiąc, iż nie rozumiem jego stanowiska w tej sprawie, i że będzie za to żałował, on zaś zaczął płakać i chciał mnie przeprosić [...] słuchałem tego z przerażeniem"122.

\footnotetext{
116 E. de Las Cases, dz. cyt., s. 179.

117 „Victoires, conquêtes, desastres, revers et guerres civiles des Français de 1792 -1815”..., dz. cyt., s. 312.

118 Tamże.

119 J. Nauroy, À propos de Royer, pharmacien en chef de l'armée d'Orient (17981801), „Revue d'histoire de la pharmacie” 1970, R. 58, nr 207, s. 227.

${ }^{120}$ L. Houdard, Le Service de Sante a l'Armee d'Egypte, , Revue des Etudes Napoleoniennes”, Janvier-Juin 1935, R. XXIV, T. XL, s. 237.

121 E. de Las Cases, dz. cyt., s. 180.

122 „Voyage en Autriche, en Moravie et en Bavière fait a la suite l'armee française pendant la campagne de 1808 par c. L. Cadet de Gassicourt”..., dz. cyt., s. 391-392.
} 
Jest rzeczą ciekawą, że notatki, jakie sporządził Cadet de Gassicourt, podobnie jak cytowane już autorstwa Desgenettes'a, nie występują w samym tekście, lecz znalazły się w przypisie - tu oznaczonym literą „A" i odnoszącym się do zasadniczego tekstu ze s. 120, gdzie dla odmiany jest oznaczony numerem „1” i wzmianką „patrz punkt A na końcu książki" - i także, co sam autor dodaje już na wstępie, zostały sprowokowane rozmową na temat książki Roberta Wilsona ${ }^{123}$.

Również Robert Sole w swojej pracy nadmienia, że kiedy Napoleon zwrócił się z żądaniem do Jeana-François Royera, ten bez najmniejszego protestu wykonał jego polecenie ${ }^{124}$. Praktycznie w identycznych słowach, podając to samo imie i nazwisko, przedstawił całe zdarzenie Patrice Bret, pisząc: ,zadanie to wziął na siebie farmaceuta Jean François Royer" 125 .

Jak podaje natomiast Tomasz Rogacki ${ }^{126}$, we wczesnych godzinach południowych dnia 27 maja 1799 r. jeden z oficerów, Antoine Lavalette, który pełnił obowiązki adiutanta Napoleona Bonapartego, zlustrował wszystkie magazyny i lazarety, po czym zameldował, że w szpitalu pozostało 11 chorych niezdolnych do transportu. Wówczas to Napoleon miał wezwać do siebie Desgenettes'a oraz Larreya, a w rozmowie z nimi padła propozycja podania chorym opium. Obydwaj lekarze odmówili, w związku z czym specyfik ten miał im podać następnego dnia, gdy z miasta będą wycofywać się oddziały tylnej straży, farmaceuta Jean-François Royer.

Znów powraca to samo nazwisko. Jest to postać doskonale znana, wymieniona m.in. w obszernej pracy Antoine'a Ballanda Les pharmaciens militaires français, który w biogramie zaznaczył: „,nazwisko Royer zostało przez kilku historyków [niestety nie podaje, o kogo chodzi] połączone z dramatem, jaki rozegrał się w Jaffie" ${ }^{127}$. Ale w Armii Orientu, która wkraczała do Egiptu, było aż dwóch farmaceutów, którzy je nosili, przy czym żaden z nich nie miał na imię Jean-François. Pierwszy z nich to Claude Royer, drugi zaś to „pharmacien de 3 classe” Andoche Royer. Takie dane podaje dokument „Etat nominatif des pharmaciens employes a l'expedition maritime de Toulon" wydany 30 kwietnia 1798 r. $^{128}$ na kilkanaście dni przed wypłynięciem w mo-

123 Tamże, s. 386.

124 R. Sole, dz. cyt., s. 90.

${ }^{125}$ P. Bret, dz. cyt., s. 248.

126 T. Rogacki, Ekspedycja egipska ..., dz. cyt., s. 301.

127 A. Balland, Les pharmaciens militaires français, Ed. L. Foulnier, Paris 1913, s. 99.

${ }_{128}$ Oryginał w zbiorach Musee du Service de Sante des Armees au Val-de-Grâce, Section „Campagne d'Egypte” Cahier 34/35. 
rze całej flotylli ekspedycji, lecz powstała już na miejscu lista płatnika z 23 sierpnia 1798 r., sporządzona w Kairze, wśród 54 farmaceutów odnotowuje już tylko jednego - Claude’a Royera ${ }^{129}$. Wyruszył on również z oddziałami do Syrii i uczestniczył w oblężeniu Saint Jean d’Acre (Akki), a później wycofywał się do Jaffy. Mógł więc podać tej trudnej do ustalenia liczbie chorych śmiertelną dawkę tureckiej trucizny. Taką sugestię można wysnuć po lekturze powstałej w $1815 \mathrm{r}$. pracy Pierre'a-Dominika Martina poświęconej kampanii w Egipcie i Syrii ${ }^{130}$. Całe zdarzenie, zgodnie $\mathrm{z}$ ówczesnym zwyczajem edytorskim, zostało zaznaczone na marginesie następującym podtytułem: „zatrucie rannych i chorych w szpitalu”"131, a w opisie sceny, która rozegrała się w szpitalu w Jaffie, można znaleźć takie zdanie: „Bonaparte nie odpowiedział mu [w domyśle Desgenettes'owi] nic i zwrócił się wprost do podległego mu farmaceuty"132. Ostatni wers jednak trochę gmatwa sprawę. Gdyby to był Claude Royer, to przy panującej podówczas tytułomanii w tekście zostałby użyty francuski zwrot „pharmacien-en Chef”, tak jak wers wcześniej „medecin-en Chef” przy nazwisku Desgenettes tutaj natomiast mamy określenie „subalterne” (dokładnie - ,podkomendny”), czyli może autor celowo zaznaczył fakt udziału Claude'a Royera w całej sprawie, w dość nietypowy sposób kończąc całe zdanie zwrotem ,już od dawna mający skamieniałe serce"133. Jest jeszcze jedna rzecz bardziej intrygująca - i o czym pisze Jacques Nauroy ${ }^{134}$ - otóż po powrocie do Kairu Claude Royer pozostał na zajmowanym przez siebie stanowisku, a ponadto otrzymał gratyfikację w wysokości ok. 500 liwrów jako „świadectwo dobroci naczelnego wodza za usługi, jakie oddał mu w Syrii”"135. Czyżby w ten sposób kupiono jego milczenie, gdyż nie otrzymał żadnego pisemnego rozkazu, że ma podać chorym truciznę, dopuszczając się tym samym czynu, który trudno jest zakwalifikować jako eutanazję, i trzeba nazwać po prostu morderstwem dokonanym z premedytacją. I coś tu musiało być - aż się prosi wprowadzić kolokwialne określenie - „na rzeczy”, gdyż Claude Royer, który przez pewien czas zajmował się jeszcze zaopatrzeniem szpitali kairskich, z czego wywiązywał się bardzo różnie,

129 Tamże, strony bez paginacji.

${ }_{130}$ P-D. Martin, Histoire de l'expédition française en Égypte, par P. Martin, Paris 1815.

${ }^{131}$ Tamże, s. 314

132 Tamże, s. 315

133 Tamże.

${ }^{134}$ J. Nauroy, dz. cyt., s. 226.

${ }^{135}$ Tamże. 
o czym świaczą zachowane dokumenty m.in. z 7 i 10 sierpnia $1800 \mathrm{r}^{136}$, prawdopodobnie prowadził też browar bądź zajmował się dystrybucją alkoholu ${ }^{137}$, aż wreszcie w drugiej połowie sierpnia 1800 r., praktycznie rok po opuszczeniu Egiptu przez Napoleona Bonapartego ${ }^{138}$, czyli osoby, która w pewien sposób go chroniła, zniknął bez śladu ${ }^{139}$. Nie wymienia go lista farmaceuów, którzy powrócili razem $\mathrm{z}$ armią do Francji, a pochodzącej 8 lutego 1802 r. ${ }^{140}$, ani dokument poświęcony zmarłym na terenie Egiptu ${ }^{141}$. Pozostał w kraju nad Nilem, nigdy nie zobaczył już rodzinnych stron, żony ani dzieci, które, o czym m.in. świadczy prośba z 1801 r. skierowana do szefa wojskowej służby zdrowia $^{142}$, żyły w nędzy.

Jest rzeczą interesującą, że Cadet de Gassicourt w swoich wspomnieniach zanotował następujący wers: „Bonaparte nigdy nie wyraził zgody na jego powrót do Francji" ${ }^{143}$. To też daje trochę do myślenia...

A sam koniec jego życia? Tutaj znów napotykamy kilka odmiennych wersji wydarzeń. Najstarsza pochodzi z 1818 r. i według niej Claude Royer po swoim zniknięciu przez pewien czas był szpiegiem tureckim w Egipcie i tam też został uduszony przez mameluków ${ }^{144}$. Według kolejnej zginął zamordowany w czasie powstania Albańczyków w 1804 $\mathrm{r}^{145}$ Taką informację przedstawia Marius F. Ossedat w swojej pracy doktorskiej Les pharmaciens pendant campagne d'Egypte, powstałej w 1942/1943 r., po czym wspomina następnie również w artykule poświęconym tym samym zagadnieniom ${ }^{146}$. Jeszcze inna wersja, która wydaje się najbardziej prawdopodobna, podaje natomiast, że po opuszczeniu Egiptu przez Francuzów Claude Royer szybko zyskał sobie w Kairze opinię nie tylko wybitnego lekarza, ale także chemika

136 Tamże.

137 P. Bret, dz. cyt., s. 179.

138 T. Rogacki, Ekspedycja egipska..., dz. cyt., s. 338.

139 J. Nauroy, dz. cyt., s. 226.

140 Musee du Service de Sante des Armees au Val-de-Grâce, Section „Campagne d'Egypte" Cahier 34/35.

${ }_{141}$ Tamże. Warto w tym miejscu nadmienić, że 28 spośród nich zmarło na dżumę.

142 Tamże.

143 „Voyage en Autriche, en Moravie et en Bavière fait a la suite l'armee française pendant la campagne de 1809 par c. L. Cadet de Gassicourt”..., dz. cyt., s. 392.

144 „Victoires, conquêtes, déesastres, revers et guerres civiles des Français de 1792-1815”..., dz. cyt., s. 312. Na marginesie warto dodać, co też jest rzeczą ciekawą, że i w tej monografii fakty dotyczące zdarzenia w Jaffie zostały zamieszczone w formie rozbudowanego - zajmującego sześć kolejnych stron (od 309 do 314) - przypisu umieszczonego pod zasadniczym tekstem.

145 J. Nauroy, dz. cyt., s. 227.

146 M.F. Ossédat, Les pharmaciens pendant l'expédition d'Egypte, „Revue d'histoire de la Pharmacie” 1942, R, 30, nr 112, s. 76-80. 
oraz farmaceuty. Powoływał się przy tym na fakt, że był ulubionym uczniem Claude'a Bertholleta i Antoine'a Lavoisier'a ${ }^{147}$. Bez problemu pracował w tym mieście, by następnie objąć stanowisko przybocznego lekarza na dworze kedywa ${ }^{148}$ Egiptu Mehmeta Ali.

Ale sumienie to straszna trucizna, co najlepiej chyba wyraził William Shakespeare, kreując postać Lady Makbet ${ }^{149}$. Claude Royer osamotniony, często miewający silne napady lęku, popadł w uzależnienie od alkoholu i zmarł z powodu zakażenia krwi po wypadku podczas przejażdżki konnej w 1818 r. $^{150}$

I tu mała uwaga na marginesie. Na karcie przedtytułowej egzemplarza książki Pierre'a-Dominika Martina, znajdującego się w zbiorach Biblioteki Narodowej Francji, można znaleźć drobną uwagę napisaną odręcznie niezbyt wyrobionym charakterem pisma: „ta historia jest pamfletem przeciwko generałowi Bonapartemu"151. Z całą pewnością nie sporządził jej Hippolyte Larrey, do którego księgozbioru należała, o czym świadczy podpis na okładce, a nie jest wykluczone, że tom ten był jeszcze własnością Dominika Jeana Larreya. Barwa papieru, na którym znajduje się ten dopisek, sugeruje, że mógł zostać sporządzony już po wykonaniu oprawy introligatorskiej tego egzemplarza. $\mathrm{Z}$ podobną uwagą, dla odmiany na tomie zachowanym $\mathrm{w}$ zbiorach $\mathrm{Bi}$ bliteki Municypalnej w Lille, spotkał się również A. Gerard. Została ona sporządzona bezpośrednio u dołu strony 315, na której znajduje się opis całego wydarzenia, jej tekst zaś brzmi: „,autor powinien zostać oskarżony o kalumnię, gdyż żaden z żołnierzy, który był w Egipcie, nie pamięta tego zbrodniczego czynu, jaki przypisuje się Bonapartemu"152. Czy obdarzany czcią cesarz mógłby wydać komukolwiek podobne polecenie...? Jak widać mógł.

Te dwa dopiski można uznać za spontaniczną rekację czytelników. Ale jest coś jeszcze. Otóż w 1831 r. ukazał się zbiór pamiętników Antoine'a Lavalette'a ${ }^{153}$, w którym można znaleźć następujący akapit: „można uznać za okropne oszczerstwo, iż Bonaparte, jak twierdzą naczelny chirurg armii Larrey, a także Desgenettes - z którym wiodę

${ }^{147}$ J. Nauroy, dz. cyt., s. 227.

${ }^{148}$ Kedyw - tytuł turecki, w imperium ottomańskim odpowiadający wicekrólowi. Nosili go zarządcy Egiptu oficjalnie od 1867 r., nieoficjalnie dużo wcześniej - od 1805 r.

149 W. Shakespeare, Makbet, Kraków 1895, s. 64-65.

150 C. d'Aguilla, Le pharmacien Royer, „Mioroir de l'Histoire” 1965, nr 192, s. 31.

151 P-D. Martin, dz. cyt., karta przedtytułowa, br. paginacji.

152 Tu za: A. Gerard, dz. cyt., s. 121.

153 A.M.Ch. LaValette, Mémoires et souvenirs du comte Lavallette, aide de camp du général Bonaparte, conseiller d'État et directeur général des postes de l'empire, Paris 1831. 
spór na łamach prasy od piętnastu lat - polecił podać chorym truciznę"154.

Napoleon dawno opuścił Jaffę. Tę z pięknego obrazu i tę rzeczywistą. Przed wielu laty odeszli już świadkowie. Lecz po owym wydarzeniu pozostał do dziś jeden bardzo ważny ślad, który nadal winien być dewizą wszystkich medyków. Słowa Desgenettes'a: „moim obowiązkiem jest ratować ludzkie życie, a nie zabijać”.

\title{
Summary
}

\section{Napoleon and plague in Jaffa - a beautiful picture... unfortunately, the less beautiful truth}

\begin{abstract}
This text is an attempt to systematize data and answer the question what happened in Jaffa during the evacuation of wounded and sick from the city during the retreat of Napoleonic troops in May 1799, and to find people who were personally responsible for administering poison to the most severely ill.
\end{abstract}

\section{Bibliografia}

„La campagne d'Égypte, 1798-1801 mythes et réalités” Actes du colloque des 16 et 17 juin 1998 à l'Hôtel national des Invalides. Ed Maissonenuve et Larose, Paris 1998.

Une biographie de Des Genettes, „Le Progres Medical Suppl. Ilustre” 1926, nr 12.

„Voyage en Autriche, en Moravie et en Bavière fait a la suite l'armee française pendant la campagne de 1809 par c. L. Cadet de Gassicourt", Paris 1818.

d'Aguilla C., Le pharmacien Royer, „Mioroir de l'Histoire” 1965, nr 192.

Balland A., Les pharmaciens militaires français, Ed. L. Foulnier, Paris 1913.

Barral G., La sante de Napoleon Ier, „Chronique Medicale” 1900, R. VII.

Barrow J., Life and Correspondence of Admiral Sir William Sidney Smith, T. 1, London 1848.

Berthier A., Relation des campagnes du General Bonaparte en Egypte et en Syrie par le général de division Berthier chef de l'etat major general de l'Armee d'Orient, Milan An. VIII.

Bielecki R., Encyklopedia wojen napoleońskich, Warszawa 2002.

${ }^{154}$ Tamże, s. 324. 
Bret P., Egipt w czasach Napoleona, Poznań 2002.

Bulos A., Bourrienne et ses erreurs volontaires et involontaires, ou Observations sur ses paires „Mémoires“ MM. le général Belliard, le général Gourgaud, le comté d'Aure, le comté de Survilliers, le Bon Meneval, le comté Bonacossi, Paris 1830.

Cabanes Dr., Blavihnac A., Correspondance de Guillaume Warden chirurgien à bord du vaisseau de Sa Majeste britannique le „Northumberland" qui a conduit Napoléon Bonaparte a l'île de Saite-Helene, „La Chronique Medicale”, 1re Decembre 1899, R. VI, nr 23.

Castellani E., Wielkie muzea. Luwr, Warszawa 2007.

M. Cazalas Discours, [w:] Inauguration de la statue du baron Larrey, chirurgien en chef des armées du premier Empire, Ed. T. Thelmon, Tarbes 1864.

Chanut J., Campagne de Bonaparte en Egypte et en Syrie par un officier de la 32 demi-brigade, Paris 1832.

Chaptal J-A., Mes souvenirs de Napoleon, Paris 1893.

Desgenettes R., Histoire médicale de l'armée d'Orient par le médecin en chef $R$. Desgenettes, Paris 1802.

Desgenettes R., Histoire medicale de l'Armee d'Orient par R. Desgenettes, Ed. Firmin Didot, Paris 1830.

Forge E., Desgenettes, „Société historique et archéologique de l'Orne. Bulletin” 1939, T. LVIII.

Gembarzewski B., Wojsko polskie. Księstwo Warszawskie 1807-1814, Warszawa 1905.

Gerard A., Bonaparte et le service de santé au cours de l'expédition d'Egypte, „Histoire des Sciences Medicales” 1974, vol. 8, T. I.

Houdard L., Le Service de Sante a l'Armee d'Egypte, „Revue des Etudes Napoleoniennes", Janvier-Juin 1935, R. XXIV, T. XL.

de La Jonquiere C., L'expedition en Egypte, 1798-1801, T. IV, Paris b.r.w.

Kark R., Jaffa: A City in Evolution 1799-1917, Jerusalem 1990.

Kubikowski P., Wardaszko-Łyskowska H. (red.), Zależności lekowe, Warszawa 1978.

de Langle F., Général Bertrand. Cahiers de Sainte-Helene, Paris 1951.

Larrey D.J., Relation historique et chirurgicale de l'armee d'Orient en Egypte et en Syrie par D-J. Larrey, Ed. Demonville et soeurs, Paris 1803.

Larrey D.J., Memoires de chirurgie militaire et campagnes de D. J. Larrey, T. I, II i III, Ed. J. Smith, Paris 1812. 
Larrey D.J., Memoires de chirurgie militaire et campagnes du baron D-J Larrey, T. IV, Ed. J. Smith, Paris 1817.

LaValette A.M.Ch., Mémoires et souvenirs du comte Lavallette, aide de camp du général Bonaparte, conseiller d'État et directeur général des postes de l'empire, Paris 1831.

La Valva V., Sabato S., Siniscalso-Gigliano G., Morphology and Alkaloid Chemistry of Papaver setigerum DC. (Papaveraceae), „Taxon”, May 1985, vol. 34, no. 2.

de Las Cases E., Memoriał ze Św. Heleny, Gdańsk 2008.

de Metz J., Legrain G., Aux pays de Napoleon. Egypte, Grenoble 1913.

Marchioni J., Place a Monsieur Larrey, Arles 2003.

Martin P-D., Histoire de l'expédition française en Égypte, par P. Martin, Paris 1815.

Marx K.F.H., Moral aspects of medical life, London 1846.

Nauroy J., À propos de Royer, pharmacien en chef de l'armée d'Orient (1798-1801), „Revue d'histoire de la pharmacie” 1970, R. 58, nr 207.

Ossédat M. F., Les pharmaciens pendant l'expédition d'Egypte, „Revue d'histoire de la Pharmacie" 1942, R, 30, nr 112.

Pariset, Eloge du Baron R. Desgenettes, Ed. Balliere, Paris 1838.

Pigeard A., Martin Y., Mont-Thabor - Saint-Jean-d'Acre - Aboukir Dossier du mois, „1798-1801 La Campagne d'Égypte” Gloire \& Empire, 2006, nr 7, cz. 2.

Pignatti S., Flora d'Italia, Edagricole, Vol. I, b.m.w. 1982.

Richardot Ch., Relation de la campagne de Syrie specialement des sieges de Jaffa et de Saint jean d'Acke par un officier d'artilerie de l'Armee d'Orient, Paris 1839.

Richet G., Aspects humanitaires et médicaux de l'Armee d'Orient (1799-1801), „Histoire des Sciences Medicales” 2003, nr 2, T. 37.

Rogacki T., Ekspedycja egipska, Zabrze 2008.

Rogacki T., Egipt 1798-1801, Warszawa 1999.

Schuermans A., Itinéraire général de Napoléon Ier, Paris 1911.

Sole R., Uczeni Bonapartego, Warszawa 2001.

Strathern P., Napoleon w Egipcie. Największa sława, Poznań 2009.

Szumlański J., Wpyprawa egipska roku 1798, Lublin 2016.

Thibeadeau A., Histoire générale de Napoléon Bonaparte, de sa vie privée et publique, de sa carrière politique et militaire, de son administration et de son gouvernements, T. II, Ed. Ponthieu, Paris 1828.

Thiry J., Bonaparte en Egypte, Paris 1978.

Triaire P., La visite de Bonaparte aux pestiferes, la légende et la vérité, „La Chronique Medicale” 15 Juin 1902, R. IX, nr 12. 
Triaire P., Dominique Larrey et les campagnes de la révolution et de l'Empire, 1768-1842, Ed. Mame. Tours 1902.

Wasserman H., Jean Dominique Larrey, chirurg Wielkiej Armii, „Medycyna” 1935, R. IX, nr 21.

Wilson R.T., History of the British expedition to Egypt, London 1803.

Wilson R., Histoire de l'expedition de l'Armee britannique en Egypte, Whitehall 1803.

Vigo-Roussillon, L'expedition d'Egypte. Fragment des memoires militaire du colonel Vigo-Roussillon, „Revue des Deux Mondes”, R. LX (Troisieme periode), T. C (1 Juillet 1890).

Victoires, conquêtes, desastres, revers et guerres civiles des Français de 1792-1815, T. X, Ed. Panckoucke, Paris 1818. 